\title{
Divided communities and contested landscapes: Mobility, development and shifting identities in migrant destination sites in Papua New Guinea
}

\author{
Gina Koczberski and George N. Curry
}

\begin{abstract}
Internal conflicts at the local and national levels in several South Pacific countries have revealed the fragility of national unity and the difficulties nations face in governing and managing their own economic development. In Papua New Guinea, the focus of this paper, an uncertain economic future for many rural and urban communities, and rising inequalities in income opportunities and access to resources, have coincided with greater intolerance of migrants at sites of high in-migration by customary landowners and provincial and local authorities. This paper draws on fieldwork undertaken in the major oil palm growing regions of Papua New Guinea where migrants from densely populated regions of the country have settled on state land alienated from customary landowners. We examine how struggles over land, resource control and development are polarising migrant and landowner identities resulting in increasing tensions and episodic communal violence. A settler identity is emerging based on a narrative of nation building and national development, while an ethno-regional identity amongst customary landowners is undermining the citizen rights of migrants and challenging the role and authority of the state in land matters.
\end{abstract}

Keywords: migration, ethnic conflict, identity, land disputes, Papua New Guinea

Internal conflicts at the local and national levels in several South Pacific countries such as Fiji, Solomon Islands and Papua New Guinea (PNG) have revealed the fragility of national unity and the difficulties nations face in governing and managing their own economic development. In PNG, the focus

Authors: Gina Koczberski and George N. Curry, Department of Social Sciences, Curtin University of Technology, GPO Box U1987, Perth WA 6845, Australia. Email: g.koczberski@exchange.curtin.edu.au and g.curry@exchange.curtin.edu.au 
of this article, recent data indicate that increasing numbers of people are moving from areas of disadvantage (mostly poorly serviced rural areas) to regions where employment opportunities and services are better (Keig, 2001). People have abandoned the idea that rural development will occur in their own areas and are now actively seeking to be part of the development process through migration.

The uncertain economic future for the majority of rural and urban populations, and rising inequalities in income opportunities and access to resources, have coincided with greater intolerance of migrant groups and attempts by governments at all levels to restrict internal migration, particularly urbanisation (Connell, 1997; Koczberski et al., 2001a). Increasingly, disputes and communal violence between migrants and customary landowners are occurring, predominantly at sites of high in-migration like urban centres, mine sites and large agricultural development projects. These events are often portrayed in the media, and by opportunist politicians, as racial or ethnic conflicts, thereby divorcing them from their wider development context and limiting the likelihood of identifying and implementing appropriate solutions.

This paper examines recent land disputes and conflicts between landowners and migrants in two of the major palm oil producing areas of PNG: West New Britain Province (WNBP) and Popondetta, Oro Province ${ }^{1}$. Tensions are widening social divisions that have existed between landowner and migrant groups and are contributing to the creation and reinforcement of separate ethno-regional and migrant identities. The paper begins by providing a background to PNG oil palm land settlement schemes (LSS), and then examines the economic and political contexts of these emerging identities to identify the factors contributing to landowner-migrant divisions. While often portrayed as 'ethnic problems', we interpret the disputes as an expression of complex social, political, economic and historical forces played out at the local and national levels.

\section{OIL PALM IN PAPUA NEW GUINEA}

Oil palm is grown in five areas in PNG: Hoskins and Bialla in WNBP, Popondetta, Milne Bay and New Ireland (Figure 1). All operate on a nucleus estatesmallholder model with smallholders supplying oil palm fruit to mills operated by nucleus estate companies. In WNBP and Popondetta, smallholder production was initially located on LSSs.

In the 1960s and early 1970s, PNG, like other colonies and ex-colonies in Africa and Asia, adopted land settlement programmes to promote agricultural and economic development. Most large-scale LSSs in PNG were established during this period under the Australian colonial administration (Makara, 1976), though some schemes were implemented following independence in 1975. All LSSs have been developed on customary land alienated by the state. The LSSs were viewed as major vehicles to increase export agricultural production, integrate Papua New Guineans into cash crop production, and to relieve population pressures in some rural areas (Hulme, 1984). The Australian Administration 


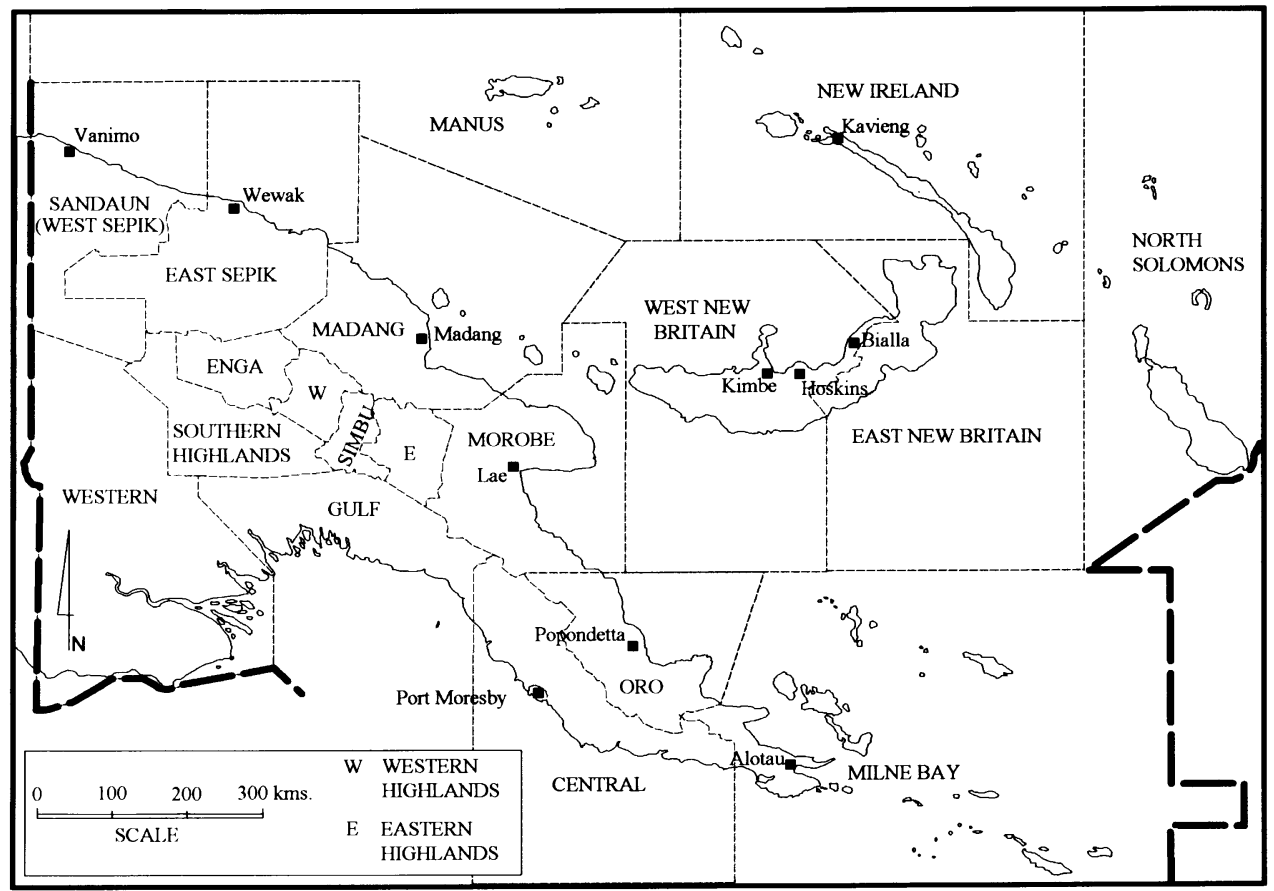

Figure 1. Locations of study sites

also considered that the establishment of LSSs would lead to an individualised land tenure system that would replace indigenous land tenure regimes grounded in kinship (Hulme, 1984: 86).

The oil palm LSSs in WNBP and Popondetta recruited people from other provinces of PNG, and settlers acquired individual 99-year agricultural leases over blocks ranging from 4 to 6.5 hectares. The agricultural leases were publicly advertised and open to all PNG residents, though priority was given to applicants from land-short areas such as the Maprik district of East Sepik Province, Chimbu and Wabag in the Highlands, and the Gazelle Peninsula of East New Britain (Hulme, 1984). Following the development and establishment of oil palm, LSSs attention turned to encouraging indigenous landowners surrounding the schemes to plant oil palm. Planting by customary landowners was negligible in the early years, but has increased markedly over the last 15 years.

Considerable socio-economic and agronomic change has occurred amongst smallholder households over the years as the smallholder sector has grown (Koczberski and Curry, 2003a, 2003b; Koczberski et al., 2001b). In 2002, smallholder production accounted for 35 per cent of total national production with the company estates producing the balance (data held by PNGOPRA). In the same year, exports of palm oil comprised 32 per cent of the total value of PNG's agricultural exports (now the largest agricultural export industry in the country), and 5 per cent of the country's exports. On several socio-economic 
variables, the oil palm growing areas in WNBP and Oro rank highly compared with other rural areas of PNG (Hanson et al., 2001).

\section{CHALLENGES TO SOCIAL STABILITY}

Despite the economic success of the oil palm industry in generating national income and regional development, several recent trends are beginning to undermine social stability in the oil palm regions. These trends include rapid population growth, the illegal sale of customary land to migrants in WNBP, and rising demands by customary landowners for compensation for LSSs and plantation estates.

\section{Population growth}

Large numbers of migrants have settled in WNBP and Oro provinces since the schemes' inception. Between 1980 and 2000, WNBP's annual population growth rate averaged 3.7 per cent, making it one of the fastest growing provinces in the country (National Statistical Office, 2001). The increase is due to both in-migration and a high rate of natural increase. At the 1990 census, 29 per cent of the WNBP population were immigrants and the province's Total Fertility Rate at over six was amongst the highest in the country.

The LSSs, especially in WNBP, have experienced considerable population growth since the late 1960s/early 1970s. Ploeg (1972: 34) reports a mean population per block of 6.0 at the end of 1970 for one of the earliest Hoskins subdivisions. Population growth rates were relatively low until about 1990 when the mean population per block for the whole Hoskins scheme reached 8.6 (Landell Mills, 1991). Since then population growth has accelerated, and in 2000 was 13.3 per block with a mean of three households per block (Koczberski et al., 2001b). The rapid rate of population growth at Hoskins LSS between 1990 and 2000 is partly attributable to the difficulties settlers now experience when attempting to resettle in their 'home' villages and the contraction of off-block residence options. Opportunities for re-establishing themselves at 'home' are becoming remote because of their long absences, together with the fact that many of their children were raised in WNBP and learned Melanesian Pidgin rather than their indigenous languages (Curry and Koczberski, 1999). Their home areas are also likely to be experiencing population and land pressures, given that settlers were initially recruited from land-short areas (Curry, 1997). Further, the large migrant population on the LSSs also attracts many short-term visitors from migrants' home provinces seeking employment, mainly on the private estate plantations (Curry and Koczberski, 1998).

The growing numbers of migrants have created a feeling among many customary landowners that they are being 'swamped' by 'outsiders'. They blame the deteriorating law and order situation on the settlers and the transient youth population attracted by work opportunities. Growing intolerance of migrants is occasionally expressed as calls to repatriate settlers and as violent disputes between settlers and landowners. 


\section{Sale of customary land}

As possibilities for returning home become more constrained through time, settlers on highly populated LSS blocks around Hoskins, WNBP, are attempting to secure additional land to meet their needs. Land acquisition is pursued through two main avenues: the 'purchase' of customary land, and the illegal occupation and planting of oil palm on state or private land. Regarding the former, some senior customary landowners have begun 'selling' land in blocks of two or four hectares for oil palm development to 'outsiders', mainly the sons of the original LSS settlers. Due to an absence of reliable data the extent of these sales is difficult to quantify, but in Gaungo Village where we conducted fieldwork in 2000, 60 per cent of smallholder oil palm blocks were registered to people from other provinces.

The sale of customary land to 'outsiders' by senior members of the landowning group is contested by younger clan members who believe they are being 'cheated' of their 'birthrights' and will themselves face land shortages in the future (similar concerns are shared by customary landowners in Riau province, Indonesia, see Potter and Badcock, this issue). As a way to maintain/regain control of their land, and hence secure their own futures, some younger clan members are reclaiming land sold to outsiders or demanding from purchasers additional cash in excess of the originally agreed 'purchase' price. These demands are contributing to deepening social cleavages between customary landowners and migrants 'buying' land as the uncertainty surrounding such land 'purchases' adds to settlers' sense of vulnerability and risk.

\section{Demands for compensation}

Compensation claims by landowners for land alienated for the LSSs and estate plantations have been an ongoing issue for the oil palm industry. Recent calls for compensation differ from earlier claims in two key respects. Many younger educated males are leading these claims on the oil palm companies and the national government, and the levels of compensation sought are comparable with the larger and more recent compensation packages negotiated in the mining and petroleum industries. Younger landowners assert that their grandfathers were not sufficiently educated to realise the true value of their land and were 'tricked' and 'cheated' into accepting inadequate compensation from the Australian colonial administration. They see themselves as righting a past wrong. At the same time, through their actions they are asserting a new power that contests the flow of economic and social benefits of oil palm to outsiders, a group that is threatening to dominate demographically as well as economically.

\section{EMERGING IDENTITIES AND THE POLITICS OF DIFFERENCE}

This section considers how the changing relationships and rising tensions between settlers and landowners are forging a stronger sense of a collective 
identity within each group. Interviews with smallholders in WNBP and Popondetta revealed a sharpening of settler and landowner identities. This process of identity formation involves the emergence of a politics of difference that plays up ethnic/migrant stereotypes, and the fears and insecurities grounded in resource competition between settlers and landowners. In both WNBP and Popondetta, ethno-regional identities are forming among landowners that have one's ethnicity, province of birth and claims to ancestral land as the primary markers for inclusion. Land, place and belonging are emphasised. Among migrants in WNBP, a shared identity is gathering strength based, not on common descent, but on shared experiences, insecurities and a constructed history of their role in national development. In this collective settler identity, nation building and development are emphasised.

In the following discussion, we unravel these emerging identities to gain a sense of the socio-political and economic processes involved in their construction, and how struggles for 'development' and secure land tenure are manifested as a heightened sense of difference between the two groups. We seek to show that the increasing tensions and episodic communal violence between migrants and landowners are more than simply an outcome of 'ethnic' conflict. Studies examining religious and ethnic conflicts at transmigration sites in Indonesia have similarly noted that such conflicts are also largely expressions of competition over local resources where ethnic and religious affinities have crystallised and been politicised as conflict developed (Acciaioli, 2001; Elmhirst, 2001; Peluso and Harwell, 2001). As Elmhirst remarks with regard to the conflict in North Lampung, Indonesia, 'conflicts over land are frequent, and among small-scale farmers they often involve the expression of cultural difference' (2001: 285). Similarly, Cliffe and Lukham commenting on internal conflicts in developing countries in the 1990s observe that the 'discontents arising from social and economic deprivation are more often articulated in ethnic, nationality or regional terms' (1999: 44). Thus, while ethnicity or other cultural/religious markers are typically portrayed as causes of conflict by the media, military and political leaders, broader historical issues involve competition for resources, economic inequalities and political and social change.

\section{Landowners and emerging ethno-regional identities}

In both WNBP and Oro Province, customary landowners do not share a common language, traditions or culture, and prior to the colonial period inter-tribal warfare was present (Waddell and Krinks, 1968; Valentine and Valentine, 1979). Land disputes persist between landowning groups, but an ethno-regional consciousness in each province is developing steadily. The formation of ethno-regional identities can be traced to the establishment of the LSSs, when large numbers of migrants settled on customary land, and landowners were marginalised in the initial development of their land for oil palm. For example, in WNBP in 1977, 75 per cent of milling and logging company employees were migrants and less than 0.5 per cent of LSS blocks were allocated to 
local landowners (Valentine and Valentine, 1979: 54-55). The stark economic disparities between landowners and migrants created a common view among local landowners that the economic development occurring in their province was at the expense of themselves, and that they had lost control over social and political issues in their 'territory' (Valentine and Valentine, 1979).

Similarly, at Popondetta, a sense of loss and economic marginalisation was articulated soon after the development of the LSS by the formation of landowner pressure groups that began seeking monetary compensation from the national government, and preferential employment and commercial opportunities from the milling company. In 1982, the first compensation payment of K200,000 was awarded to Sangara Pressure Group, a landowning group representing several villages. Initial shared experiences and grievances amongst indigenous landowners provided a focus for the development of a common identity, which helped differentiate them as a group from migrants; in their common experience as landowners they had benefited less than migrants from the 'development' occurring on 'their' land.

Several local and national events and trends over the last 10-15 years have strengthened a common identity amongst landowners. One major factor that has fostered an ethno-regional identity among landowners is the manipulation of anti-migrant sentiments and anxieties by provincial leaders and aspiring politicians attempting to mobilise support during election campaigns. In the 1992 elections in Popondetta, the successful candidate for governor pursued an 'Oro-for-Oro' campaign, based on a rhetoric of 'invasion' by 'outsiders' and a local population being 'ripped off' by 'foreigners' (people from other provinces). During the election, several hundred settler families from several LSS subdivisions were violently evicted from their blocks by landowners, or abandoned their blocks in a widespread climate of fear and intimidation. A year later, a 'West-for-West' campaign was employed in the West New Britain provincial elections. In 1993, 173 settler families making up the Kavugara LSS subdivision in Hoskins, WNBP, were evicted from their blocks by customary landowners during violent confrontations. The Oro-for-Oro and West-for-West campaigns were based on the premise that both provinces should be developed and controlled by the indigenous population, not by 'outsiders'. Both campaigns manipulated customary landowner fears about demographic and economic dominance by 'outsiders', fears that related to their future security and well-being on their own land. Landowner grievances were politicised and given legitimation in electoral campaigns that heightened their fears and resentment from which ethno-regional identities exclusive of 'outsiders' materialised. As Igwara (2001: 95) reports for Nigeria, 'what is manipulated is not the identity of the group members, but their fears about dominance', a fear exacerbated in the Popondetta elections by a popular and successful 'outsider', a migrant businessman from the Southern Highlands who stood for election.

Since the mid-1990s elections, public pronouncements have been made regularly by WNBP political leaders calling for the repatriation of settlers following crimes committed by settlers or their visitors (PNGPC, 1995, 1998) 
(see below). In the rhetoric of clamping down on crime, anti-migrant sentiments reinforce an ethno-regional identity exclusive of outsiders. In Popondetta, intimidation of migrants continues as emphasised by one settler in an interview in 2001: 'Oro-for-Oro igo iet' (the Oro-for-Oro campaign is still going on, implying intimidation and harassment of settlers continues). Since the election, landowners have imposed restrictions on the economic activities of LSS leaseholders on their blocks, and have vigorously opposed the replanting of senile oil palms by settlers. Leaseholders are prevented from establishing small businesses such as stores and poultry projects, and are discouraged from harvesting too much oil palm fruit because if their incomes are perceived to be high, they become targets for harassment and monetary demands ${ }^{2}$. Landowners explained to us their opposition to settlers managing small businesses on their blocks in terms of the lease arrangements, that is, there were no provisions in LSS leases for settlers to earn income from sources other than oil palm.

Oil palm and the land on which it is cultivated are viewed by landowners as separate resources, each with different sets of rights. Because customary landowners see themselves as the rightful 'owners' of the land they view their actions against settlers as morally legitimate responses to their predicament. As one landowner remarked to a settler wanting to replant his 18-year-old palms: 'yu kaikai inap pinis - yu go nau' - (you have had your share [income from oil palm] - time to go). Such demands signify a resurgence in the moral

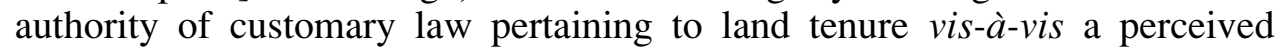
diminishing authority of the state in land matters.

The electoral campaigns are significant for understanding the recent hardening of a place-based identity among landowners because they were focal points around which the disparate discontents of landowners coalesced and were given form as anti-settler sentiments. Migrants continue to be stereotyped as thieves and criminals, the cause of the breakdown in law and order, gaining preferential employment, stealing the 'birthrights' of customary landowners and being disrespectful of local cultures. In the case of WNBP, the rising demographic dominance of migrants is also seen as a threat to local people's identity and existence. For local people, employment constraints, marginalisation from the economic gains of oil palm on 'their' land and economic hardships are often expressed in terms of migrants' presence in the province. These stereotypes of migrants, which are based largely on unfounded fears and anxieties, set migrants apart from the indigenous population and work to produce a greater sense of commonality and identity among the local population, where one did not exist previously (see Barth, 1982).

Cross-cutting these locally based processes that are constructing a common identity amongst landowners are broader national trends in which place, locality and land ownership are gaining importance. These national trends are expressed as attempts to stem internal migration in PNG, the widespread rise of assertive landowner groups and the emergence of stronger regional identities. Landowner opposition to 'outsiders' is rising in many provinces. It is in the urban centres where most public opposition to migrants (and the growth of 
informal settlements) occurs and which is reported widely in the media. For example, evictions from informal settlements and intermittent calls for the Vagrancy Act to be reintroduced have been prominent administrative responses to continuing urban growth and growing law and order problems (Koczberski et al., 2001a; PNGPC, 2003a, 2003c), especially as urban crime is now considered to be a major factor deterring foreign investment in PNG (Levantis, 2000).

In urban areas provincial and local community leaders often play up the negative stereotypes of migrants as criminally inclined and usurping customary landowners' birthrights. Such actions against migrants and the reassertion of place and locality in urban centres now colour the discourse and attitudes of some provincial authorities and indigenous communities in non-urban settings such as the main areas of oil palm development in PNG. This process is creating a space in which landowners' intimidation and harassment of settlers is legitimised.

Linked with intolerance of migrants is the growing assertiveness of landowners in their relationships with the state and capital, as illustrated by the rising number of compensation claims and other landowner demands on government and developers (see Filer, 1997). Previously, most compensation demands were for land alienated by the state or developers for rural or resource development projects or urban development, but more recently such demands have included long-standing public infrastructure such as airports, roads, communication towers and health centres. Standish (2001: 290) notes 'Local landowners are making compensation claims over infrastructure such as roads and schools which they use themselves and which were negotiated decades ago by the Australian colonial administration'. In a further twist in these demands, a group of Goroka water resource owners and landowner groups have requested that their provincial government implement a preferential work policy for them as customary resource owners (PNGPC, 2003b). The rising number of compensation claims and other landowner demands point to landowners' attempts to reclaim ownership and control of alienated land by reasserting their customary rights as landowners. In so doing they are directly challenging state authority, and 'deny[ing] the state's right to govern, both symbolically and in practice' (Standish, 2001: 290).

The increasing assertiveness of landowners in their dealings with the state and capital, and the growing opposition of local and national, in PNG, mean that with a declining state capacity to govern, new political spaces are opening for the expression of new forms of regional identity and political authority. Such assertions of place-based identities can be seen in the growth of several identifiable regional identities in PNG (Clark, 1997; Jorgensen, 1996; Matthew, 2000) and localised opposition and disregard for national government institutions and legal frameworks. The most dramatic recent expressions were the secessionist war on the island province of Bougainville and the 2002 national elections where, in some Highland electorates, local tribal allegiances overrode constitutional democratic electoral procedures. In each event there was greater identification with the clan, ethnic group or province than with the 
concept of nation, and there was a rejection of the political sovereignty of the state. In the well-documented case of Bougainville, among the most common justifications for secession were Bougainvilleans' claim of ethnocultural distinction and the need for cultural preservation (Matthew, 2000).

It can be argued in the case of the economically successful oil palm regions in Oro and WNBP that the decline of government services and deteriorating infrastructure brings into question the credibility of the national government and enables the rise of a regional politics and identity to emerge.

\section{Settler (Vaira/Weira) identities}

The term vaira, is from the Gunantuna language of Gazelle Peninsula, East New Britain and refers to strangers/outsiders that do not belong to the same land, language or descent group (Zwinge, 1953: 4). Now the term has wider currency, and is used by customary landowners in WNBP and Popondetta to label settlers and other migrants. While the literal meaning implies exclusion and difference, it is increasingly being adopted as an umbrella label by the multi-ethnic settler population to forge among themselves a shared identity and collective consciousness. At a political level, a vaira identity binds settlers in opposition to local landowners and is growing in strength as settlers begin to acknowledge their common history, fears and tenure insecurities, and, a common threat - the customary landowners. At a community level, a multi-ethnic vaira identity is evolving as settlers' common interests and bonds increase, particularly through inter-ethnic marriages among second and third generation settlers. Thus, identifying with the multi-ethnic vaira group is increasingly possible and politically strategic.

Generally, ethnic affinity still overrides vaira identity. Ethnic associations on the LSSs remain strong and some ethnic associations continue to lobby their home provincial governments for the establishment of LSSs in their home provinces and their repatriation to these schemes. Thus, the shared vaira identity based on a common threat is unstable and varies in strength in response to the perceived level of external threat. When tensions between customary landowners and settlers are high, ethnic identity amongst migrants is subsumed within a broader settler identity. When tensions subside, ethnicity assumes more importance. However, it appears that a common settler identity is becoming more entrenched through time as settlers' tenure security is increasingly challenged by landowners, and as inter-marriage increases amongst settlers of different ethnic origin.

Several events have helped galvanise a level of unity amongst settlers to confront an increasingly uncertain future. First, the large-scale evictions at Kavugara and Popondetta, the ongoing income restrictions imposed by landowners on Popondetta settlers, and two other less violent attempts to evict Hoskins LSS settlers have brought settlers together to re-evaluate their relations with each other and their host societies. Another incident, but further afield, was the protracted secessionist war on Bougainville that erupted in 1988 in response to unresolved landowner grievances over the Panguna 
copper mine. During the war migrant workers and their families were targeted with violence and forced to flee. Several smallholder settlers in WNBP referred to the Bougainville crisis as a possible scenario for WNBP. However, rather than fleeing the province, these migrants claimed adamantly that they would fight to remain living on the LSS. As one second generation Highlander remarked in regard to possible future attempts to evict his family from their LSS block:

Where will we go? ... This is our home. Our parents and relatives are buried here on the blocks or at the LSS cemetery. We will fight to stay or the government must pay adequate compensation [for us to leave]. (Buvussi settler: 25/10/00. Translated from Melanesian pidgin.)

Other threats to settlers' long-term security that reinforce a vaira consciousness are the occasional calls of provincial authorities to repatriate settlers, usually following a spate of crimes committed by vaira. Calls for repatriation define settlers as a homogenised group of 'non-citizens' without moral rights to the land they occupy. Settlers are criticised for not respecting local people and their customs, which is a reminder to settlers of their obligations to customary landowners for living on their land. Such a discourse promotes and legitimises the political power of landowners. Because the LSSs were established by the colonial authorities and responsibility for the schemes passed to the national government on independence, this discourse pits a regional moral authority against a distant and amoral national government, a discourse that highlights a corrupt and ineffectual national government. In this discourse the interests of customary landowners are best served by the provincial authorities, not the national government which has taken over the mantle of a distant and unknowable colonial authority. The interests of settlers are excluded in this discourse. The discourse of a regional moral authority reinforces the belief of some settlers that the provincial administration is supporting customary landowners' claims for land and compensation.

To legitimise their tenure rights, settlers attempt to counter this anti-migrant discourse by constructing a vaira identity in terms of nation building; a narrative that places the 'hard-working' settler at the centre of national development and advancement. Many original settlers in WNBP claim the province was 'undeveloped' before they arrived and cleared the logged-over forest for oil palm. These settlers assert that local landowners did not possess the same level of work ethic as themselves, and were not interested in participating in modern economic development. It was through the settlers' hard work, they maintain, that WNBP is today one of the most economically successful provinces in the nation. They cite the much lower productivity levels of village oil palm smallholders relative to themselves, and the dominance of migrants in small business ventures in the provincial capital of Kimbe as evidence of their significant role as agents of national economic development. In this way, settlers are constructing an identity that celebrates themselves as hard-working, forward looking and occupying a special place in the nation's development. 
The narrative of nation building expressed by settlers provides a mantle of superiority over customary landowners in the sense that settlers are modern, educated and engaging in the market economy. In contrast, landowners are constructed as backward-looking, lazy and focused on parochial issues with little to contribute to the project of nation building. Such a constructed identity and ideology reverses the superiority of landowners over migrants asserted by provincial and indigenous community leaders, thereby challenging the power and authority of landowners.

The legitimacy of settlers' LSS leases is grounded in modern notions of development and land legislation rather than in traditional aspirations and customary laws governing land tenure. In the absence of customary rights to land, it is imperative for leaseholders to attach themselves to the state through a narrative of nation building. An interesting aspect of this narrative is the construction of a set of migrant 'traditions', beliefs and myths, which are central to forging a unified common identity (Anderson, 1991; Lawson, 1997; Turner, 1997). This constructed historical role of settlers in the past and present development of the province and nation reinforces their leasehold rights to the land they developed. In these ways the opposition between settler and landowner identities are constructed along two axes: national-provincial and moderntraditional, which draw on different ontologies to legitimise land claims and identity.

\section{CONCLUSION}

In struggles over land, resource control and development, landowner and migrant identities are becoming polarised as their interests diverge through time. Local landowners and provincial authorities nationwide are challenging internal migration and the citizenship rights of migrants. An element of these challenges is an emphasis on place and belonging, as landowners, through much of PNG, attempt to reclaim ownership and control of alienated land and other natural resources. Thus, identity formation among landowners contains a discourse of a morally legitimate indigenous claim to ancestral land alienated by the state (for examples from Southeast Asia, see Barney, this issue). While these trends may be interpreted positively as increased autonomy for customary landowners, or as a form of resistance to globalisation (see Escobar, 2001), such 'place-based essentialism' (Elmhirst, 2001: 293) undermines the security of settlers, denies their rights to land, and erodes possibilities for fostering civil society.

Countering the place-based discourse of provincial and indigenous leaders that challenge settlers' presence in the province, settlers invoke narratives of nation building and national development. In doing so, settlers align themselves with the state for it is on the state's institutions and laws (and not customary law or tradition) that settlers' legitimacy as leaseholders depends. Unfortunately for settlers, the authority and credibility of the state in rural areas is being contested and eroded gradually by customary landowners, the most prominent and tragic example being the Bougainville War. 
Yet, despite the deepening divisions between landowners and settlers we should be mindful that identity is fluid and possibilities remain for building more inclusive and tolerant communities. Landowner and migrant constructed identities are recent and unstable, and clan and ethnicity can take prominence over ethno-regional and vaira identities. Further, there are instances in WNBP of 'outsiders' being integrated successfully into their host societies with relatively secure access to resources. Typically, in such cases, migrants have become embedded in the social and economic networks of their hosts. These relationships between landowners and settlers have their roots in indigenous mechanisms of group formation and identity. Indigenous exchange facilitates social inclusion and enhances tenure security. Such transactions are outside the market economy and the Western notion of land as a commodity. The fact that such strategies are being pursued successfully by some migrants, even in the broader context of landowner-settler tensions and conflict, point to some potential long-term solutions involving customary land tenure which draw on elements and principles of non-market economic and social relations for their validity and recognition.

\section{ACKNOWLEDGEMENTS}

An ARC Small Grant funded initial fieldwork in WNBP in 1995. Additional data were collected during fieldwork for a collaborative smallholder oil palm project with The Australian National University (K. Gibson) and the PNG Oil Palm Research Association, with funding from the Australian Centre for International Agricultural Research.

\section{NOTES}

1 Data were collected during nine months' fieldwork in the land settlement and village oil palm schemes in WNBP (1995/96 and 2000/2) and Popondetta (2000/2001) and in Miko village, Wosera sub-district, East Sepik Province (1996 and 1998). The research employed mainly ethnographic techniques and entailed a relatively long period of fieldwork and engagement with communities at each site.

2 Popondetta is the only scheme in PNG where settler oil palm productivity is lower than that of customary landowners.

\section{REFERENCES}

Acciaioli, G. (2001) Grounds of conflict, idioms of harmony: custom, religion, and nationalism in violence avoidance at the Lindu Plain, Central Sulawesi, Indonesia 72: 81-112.

Anderson, B. (1991) Imagined communities: reflections on the origin and spread of nationalism, revised edition, London and New York: Verso.

Barney, K. (this issue) Re-encountering resistance: plantations, activism and smallholder production in Thailand and Sarawak, Malaysia, Asia Pacific Viewpoint 45(3): 325-339.

Barth, F. (1982) Introduction, in F. Barth (ed.), Ethnic groups and boundaries. The social organisation of culture difference, $2^{\text {nd }}$ reprint, Oslo: Universitetsforlaget, 9-38.

Clark, J. (1997) Imagining the state, or tribalism and the art of memory in the Highlands of Papua New Guinea, in T. Otto, and N. Thomas, (eds), Narratives of nation in the South Pacific, Amsterdam: Harwood Academic Publishers, 65-90. 
Cliffe, L. and R. Luckham (1999) Complex political emergencies and the state: failure and fate of the state, Third World Quarterly 20(1): 27-50.

Connell, J. (1997) Papua New Guinea: the struggle for development, London: Routledge.

Curry, G.N. (1997) Warfare, social organisation and resource access amongst the Wosera Abelam of Papua New Guinea, Oceania 67(3): 194-217.

Curry, G.N. and G. Koczberski (1998) Migration as a way of life for the Wosera Abelam of Papua New Guinea, Asia Pacific Viewpoint 39(1): 29-52.

Curry, G.N. and G. Koczberski (1999) The risks and uncertainties of migration: an analysis of recent trends amongst the Wosera Abelam of Papua New Guinea, Oceania 70(2): 130145.

Elmhirst, R. (2001) Resource struggles and the politics of place in North Lampung, Indonesia, Singapore Journal of Tropical Geography 23(3): 284-306.

Escobar, A. (2001) Culture sits in places: reflections on global and subaltern strategies of localisation, Political Geography 20: 139-174.

Filer, C. (1997) Compensation, rent and power in Papua New Guinea, in S. Toft (ed.), Compensation for resource development in Papua New Guinea, Canberra: Law Reform Commission of Papua New Guinea and Resource Management in Asia and the Pacific, Research School of Pacific and Asian Studies, The Australian Nation University, 156190.

Hanson, L.W., B.J. Allen, R.M. Bourke and T.J. McCarthy (2001) Papua New Guinea rural development handbook, Canberra: Land Management Group, Department of Human Geography, The Australian National University.

Hulme, D. (1984) Land settlement schemes and rural development in Papua New Guinea, Unpublished PhD thesis, Queensland: James Cook University.

Igwara, O. (2001) Dominance and difference: rural visions of ethnicity in Nigeria, Ethnic and Racial Studies 24(1): 86-103.

Jorgensen, D. (1996) Regional history and ethnic identity in the hub of Papua New Guinea: the emergence of the Min, Oceania 66: 189-210.

Keig, G. (2001) Rural population growth in Papua New Guinea between 1980 and 1990, Asia Pacific Viewpoint 42(2/3): 255-268.

Koczberski, G., G.N. Curry and J. Connell (2001a) Full circle or spiralling out of control? State violence and the control of urbanisation in Papua New Guinea, Urban Studies 38(11): 2017-2036.

Koczberski, G., G.N. Curry and K. Gibson (2001b) Improving productivity of the smallholder oil palm sector in Papua New Guinea, Canberra: Department of Human Geography, Research School of Pacific and Asian Studies, The Australian National University.

Koczberski, G. and G.N. Curry (2003a) Sustaining production and livelihoods among oil palm smallholders: a socio-economic study of the Bialla smallholder sector, Perth: Research Unit for the Study of Societies in Change, Curtin University of Technology.

Koczberski, G. and G.N. Curry (2003b) Creating viable livelihoods amongst oil palm smallholders in Papua New Guinea, in O. Metz, R. Wadley, and A.E. Christensen (eds), Local land use strategies in a globalising world: shaping social and natural environments, Copenhagen, Denmark: Institute of Geography, University of Copenhagen, Volume 4: 107-129.

Landell Mills Ltd. (1991) Smallholder oil palm productivity study, volume 1: main report, Bath: United Kingdom.

Lawson, S. (1997) Cultural traditions and identity politics: some implications for democratic governance in Asia and the Pacific, State Society and Governance in Melanesia Discussion Paper 97/4, Canberra: Research School of Pacific and Asian Studies, The Australian National University.

Levantis, L. (2000) Crime catastrophe - reviewing Papua New Guinea - it's criminal, Pacific Economic Bulletin 15(2): 130-142.

Makara, L. (1976) West New Britain Province, Harvest 3(4): 140-148.

Matthew, A. (2000) Bougainville and Papua New Guinea: complexities of secession in a multiethnic developing State, Political Studies 48: 724-744. 
National Statistical Office (2001) National population and housing census 2000, Port Moresby: National Statistical Office.

PNGPC (Papua New Guinea Post Courier) (1995) Waka: oil palm growers need K1.8m payout, 5 December.

PNGPC (Papua New Guinea Post Courier) (1998) Oil palm settlers face angry locals, 15 September.

PNGPC (Papua New Guinea Post Courier) (2003a) Focus: Yali brings new era to Madang, 11 March.

PNGPC (Papua New Guinea Post Courier) (2003b) Landowners upset, 20 June.

PNGPC (Papua New Guinea Post Courier) (2003c) Editorial: focus on urban centres long overdue, 8 July.

Peluso, N.L. and E. Harwell (2001) Territory, custom, and the cultural politics of ethnic war in West Kalimantan, Indonesia, in N.L. Peluso and M. Watts (eds), Violent Environments, New York: Cornell University Press, 83-115.

Ploeg, A. (1972) Sociological aspects of Kapore settlement, in J.P. Longayroux, T. Fleming, A. Ploeg, R.T. Shand, W.F. Straatmans and W. Jonas (eds) Hoskins development: the role of oil palm and timber, Canberra: New Guinea Research Bulletin No. 49, Australian National University, 21-118.

Potter, L. and S. Badcock (this issue) Tree crop smallholders, capitalism, and Adat: studies in Riau Province, Indonesia, Asia Pacific Viewpoint 45(3): 341-356.

Standish, B. (2001) Papua New Guinea in 1999-2000, Journal of Pacific History 36(3): 285298.

Turner, J.W. (1997) Continuity and constraint: reconstructing the concept of tradition from a Pacific perspective, The Contemporary Pacific 9(2): 345-381.

Valentine, C.A. and B. Valentine (1979) Nakanai: villagers, settlers, workers and the Hoskins oil palm project, in C.A. Valentine and B. Valentine (eds), Going through changes: villagers, settlers and development in Papua New Guinea, Canberra: New Guinea Research Unit, The Australian National University, 48-71.

Waddell, E.W. and P.A. Krinks (1968) The organisation of production and distribution among the Orokaiva, New Guinea Research Bulletin 24, Canberra: New Guinea Research Unit, The Australian National University.

Zwinge, H. (1953) A Grammar of the Gunantuna Language, Published by author (Zwinge). 